\title{
Ingestive behavior and displacement patterns of beef heifers on Italian ryegrass pasture
}

\section{Carine Lisete Glienke ${ }^{1}$, Marta Gomes da Rocha ${ }^{2}$, Dalton Roso ${ }^{1}$, Luciana Pötter ${ }^{3}$, Vagner Guasso da Costa ${ }^{1}$, Juliana Medianeira Machado ${ }^{1}$}

\author{
${ }^{1}$ Programa Pós-graduação em Zootecnia, Universidade Federal de Santa Maria - UFSM, RS \\ 2 Departamento de Zootecnia, UFSM, RS. \\ 3 UFSM/CESNORS - Palmeiras das Missões, RS.
}

\begin{abstract}
The effect of supplementation on ingestive behavior and displacement patterns of beef heifers grazing on Italian ryegrass (Lolium multiflorum Lam.) pasture was evaluated. The grazing method was continuous with variable stocking rate. The experimental design was completely randomized with repeated measures on time. The supplement utilized was a commercial ration $(17 \% \mathrm{CP}, 21.4 \% \mathrm{NDF})$, daily supplied at $2 \mathrm{pm}$, in the proportion of $1 \%$ of body weight. The evaluations were made through visual observations, in four continuous periods of 24 hours. There was no difference in the bite rate between heifers with and without supplement and bite rate was higher at the end of the period of pasture utilization. Supplemented animals increased bite mass. The number of stations/minute, bites/station and the displacement patterns was influenced by forage changes along the occupation period. The ingestive behavior and displacement patterns of heifers are modified by supplementation and structural variation of the grass along its biological cycle. In the reproductive stage of Italian ryegrass, grazing time, daily number of bites and, feeding stations and time for station are similar between not supplemented and supplemented heifers.
\end{abstract}

Key Words: feeding stations, grazing time, Lolium multiflorum, supplementation

\section{Comportamento ingestivo e padrões de deslocamento de bezerras de corte em pastagem de azevém}

RESUMO - Avaliou-se a influência da suplementação no comportamento ingestivo e nos padrões de deslocamento de bezerras de corte em pastagem exclusiva de azevém (Lolium multiflorum Lam.). Utilizou-se o método de pastejo com lotação contínua e número variável de animais, em delineamento inteiramente casualizado, com medidas repetidas no tempo. Os animais receberam ração comercial $(17 \% \mathrm{~PB}, 21,4 \% \mathrm{FDN})$ na proporção de $1 \%$ do $\mathrm{PV}$, fornecida diariamente às 14 h. As avaliações foram feitas por meio de observação visual, em quatro períodos contínuos de 24 horas. A taxa de bocados não diferiu entre bezerras com e sem suplementação, mas foi maior no período final de utilização da pastagem. Animais sob suplementação realizaram bocados mais pesados. O número de estações/minuto, de bocados/estação e os padrões de deslocamento são influenciados pela variação do pasto ao longo da utilização da pastagem. O comportamento ingestivo e os padrões de deslocamentos das bezerras variam quando os animais recebem suplemento e quando há variação estrutural do dossel ao longo do ciclo biológico do pasto. No estádio reprodutivo do azevém, o tempo de pastejo, o número diário de bocados e de estações alimentares e o tempo por estação são semelhantes entre bezerras que recebem ou não suplemento.

Palavras-chave: estações alimentares, Lolium multiflorum, suplementação, tempo de pastejo

\section{Introduction}

Cool-season pastures, in Rio Grande do Sul, are usually used for beef cattle growing and fattening. Supplementation of cattle grazing winter pastures is interesting for providing a more balanced nutrient supply, substitute supplement for forage where it is desirable to increase stocking rate and under conditions of low availability of grass (Horn et al., 2005).
Energy supplementation in high-quality pasture synchronizes the rate of nitrogen supply for ruminant and it may improve the grass protein utilization, which is rapidly degraded in the rumen, increase microbial protein synthesis, reduce the losses of nitrogen in the urine and increase animal performance (Rearte \& Pieroni, 2001).

New factors affect the nutrient intake when cattle are receiving supplements (Hodgson, 1990). Supplementation reduces grazing time of animals in relation to non- 
supplemented ones, without changing their forage intake (Bremm et al., 2005). Increased levels of supplement for beef heifers causes a decrease in grazing time and an increase in idle time. Rumination time remains the same, conditioning different bite rates during the grass biological cycle (Macari et al., 2007).

In addition to set of daily activities of feeding behavior, the mechanisms that regulate the process of grazing include times the animal will show preference for certain sites, which involve a number of feeding stations or clusters of patches (Carvalho et al., 2001). The time spent by animals at feeding stations - corresponding to the accessible area when its forefeet are stationary - is influenced by the green leaf blade supplement (Prache \& Rouguet, 1996). Levels of $350 \mathrm{~kg} / \mathrm{ha}$ of green leaf biomass on oats and Italian ryegrass pasture does not affect the time spent at the same feeding station by steers or the distance between them, but make animals increase bite rate (Trevisan et al., 2005).

Knowledge about the effects of supplementation and structure of winter pasture on feeding behavior of heifers can be improved by studying the process of selecting areas for grazing. In this study it was analyzed the influence of supplementation on the ingestive behavior and displacement patterns of beef heifers grazing exclusively Italian ryegrass.

\section{Material and Methods}

The experiment was carried out from May to October 2006, at the Universidade Federal de Santa Maria (UFSM), located at Depressão Central physiographic region of Rio Grande do Sul, Brazil. The climate in the region corresponds to the humid subtropical, a Cfa type according to the Köppen classification (Moreno, 1961). The temperature and daily insolation data at ingestive behavior evaluation dates were recorded at the Estação Metereológica of UFSM (Table 1).

Table 1 - Temperature and daily insolation on ingestive behaviour evaluation dates

\begin{tabular}{lcccc}
\hline Date & \multicolumn{3}{c}{ Temperature $\left({ }^{\circ} \mathrm{C}\right)$} & Insolation \\
\cline { 2 - 4 } & Maximum & Minimum & Average & (hours) \\
\hline $08 / 19 / 2006$ & 19.0 & 13.9 & 15.7 & 0.0 \\
$08 / 20 / 2006$ & 22.2 & 14.5 & 17.9 & 1.2 \\
$09 / 07 / 2006$ & 20.4 & 5.7 & 12.5 & 10.4 \\
$09 / 08 / 2006$ & 23.2 & 8.3 & 15.8 & 10.3 \\
$09 / 28 / 2006$ & 24.6 & 11.1 & 17.4 & 10.9 \\
$09 / 29 / 2006$ & 28.0 & 13.8 & 21.2 & 8.7 \\
$10 / 11 / 2006$ & 25.8 & 16.1 & 20.1 & 7.1 \\
$10 / 12 / 2006$ & 31.8 & 17.3 & 24.1 & 7.8 \\
\hline
\end{tabular}

The experimental animals were Charolais and crossbred Nellore $\times$ Charolais heifers, at approximately eight months of age with an average initial body weight of $158.3 \pm 17.1 \mathrm{~kg}$. Heifers were kept exclusively on Italian ryegrass (Lolium multiflorum Lam.) pasture, on Italian ryegrass plus red clover (Trifolium pratense L.) LE 116, or on Italian ryegrass pasture and receiving $1 \%$ body weight/day of supplement (Roso et al., 2009). There was no difference on botanical composition or sward structure $(\mathrm{P}>0.05$ ) between exclusively Italian ryegrass and Italian ryegrass plus red clover pastures. So, for ingestive behavior and displacement patterns study, the paddocks corresponding to these pastures were considered replications.

The experimental area was divided into eight paddocks (experimental units) totalizing 6.0 ha plus a reserve area of approximately $1.8 \mathrm{ha}$. The mean values for chemical characteristics of the soil on the experimental area are: $\mathrm{pH}-\mathrm{H}_{2} \mathrm{O}: 4.8$; Ca: $2.6 \mathrm{cmolc} / \mathrm{dm}^{3} ; \mathrm{Mg}: 2.5 \mathrm{cmolc} / \mathrm{dm}^{3}$; Al: 0.9 cmolc $/ \mathrm{dm}^{3}$; CTC effective: 7.0 cmolc $/ \mathrm{dm}^{3}$; CTC pH 7.0: 16.8 cmolc/ $/ \mathrm{dm}^{3}$; Al saturation: $15.4 \%$; saturation basis: 42.6\%; SMP:5.3; MO:3.0\%,P:4.7mg/dm³:K:57 mg/dm³.

The pasture was established on 05/09/2006. The sowing of Italian ryegrass was carried out with the use of mechanical planter, using $40 \mathrm{~kg} / \mathrm{h}$ a of seeds plus $10 \mathrm{~kg} / \mathrm{ha}$ of red clover seeds. Paddocks received $200 \mathrm{~kg} / \mathrm{ha}$ of a 05:20:20 compound fertilizer (N:P:K). The nitrogen fertilization was $67.5 \mathrm{~kg} / \mathrm{ha}$ of $\mathrm{N}$ in urea form, subdivided in three equal applications.

The supplement used was a commercial ration $(17.0 \%$ crude protein; $21.4 \%$ neutral detergent fiber; $59.6 \%$ total digestible nutrients) consisting of ground corn, soybean meal, wheat bran and rice meal. Heifers were daily supplemented at 2 p.m. The animals had free access to water and mineral salt.

The utilization of pasture, for forage sampling, was divided into four periods (08/4-26/2006, 08/27 to 09/8/2006, 09/9-30/2006, 10/1-14/2006), that corresponded to vegetative stage of ryegrass on first three dates and the beginning of flowering stage on the fourth. The grazing method used was continuous stocking, with three testers per paddock and a variable number of additional heifers to keep the forage mass between 1,000 and $1,500 \mathrm{~kg} / \mathrm{ha}$ of dry matter.

The forage mass was determined by the direct visual estimation method with double sampling (Gardner, 1986), carried out in a ten day- interval. In the collected samples, it was determined the partial DM of the forage and its botanical and structure composition through the manual separation of the components: leaf and stem (leaf sheath+stem) of Italian ryegrass, dead material, red clover (leaflets+stem) and other species. This material was dried at $55^{\circ} \mathrm{C}$ for 72 hours and, after this, it was weighed to 
calculated the percentage of each component, the mass of each component, in $\mathrm{kg} / \mathrm{ha}$ of dry matter and leaf:stem ratio. In the same places where the herbage mass was estimated, it was measured the canopy height by measuring the distance from the ground to the height of the folding of leaves of the ryegrass.

The rate of herbage accumulation ( $\mathrm{kg} / \mathrm{ha} / \mathrm{day}$ of DM) was estimated by using three exclusion cages located at each paddock. The forage losses were determined by the methodology proposed by Hillesheim (1998). The total production of dry matter per paddock was estimate by the sum of production in each period (daily accumulation rate $\times$ days in the period) plus forage mass at the beginning of grazing.

The stocking rate ( $\mathrm{kg} / \mathrm{ha}$ of live weight), per period, was calculated by the sum of the testers weight plus the average weight of animals used for adjustments in the stocking rate multiplied by the number of days, divided by the days of the trial period and the average weight of the testers animals.

Ingestive behavior was assessed by visual observation (Jamieson \& Hodgson, 1979) in four continuous 24-hour periods, on August $19^{\text {th }}-20^{\text {st }}$, September $7^{\text {th }}-8^{\text {th }}$, September $29^{\text {th }}-30^{\text {th }}$ and October $11^{\text {th }}-12^{\text {th }}$. Three testers were observed in each paddock, identified with earrings and numbered for easier identification. During each 24-hour the activities of grazing, idling or ruminating were recorded at 10 minutes intervals. For supplemented animals it was recorded the time spent at the trough. Grazing time was considered the time spent by animals in selection and apprehension of forage, including the short periods used in displacements for forage selection (Hancock, 1953). The idle time corresponded to the rest period and performance of other activities, like drinking water and consuming salt. The rumination time was considered the period of cessation of grazing and the completion of mastication. The time spent at the trough was considered as the time used for consumption of supplement. From these data, grazing, idle, rumination and time at the trough were calculated in minutes/day.

Bite rate (bite/minute) was evaluated during day time, when heifers were in grazing activity, at every 10 minutes, by measuring the time taken by animals to make twenty bites (Hodgson, 1982) which, multiplied by grazing time resulted in the daily number of bites. Also, it was recorded the time spent by the animal to go through ten feeding stations and the number of steps between these stations. Feeding station was defined as the space corresponding to grazing, without movement of the forelegs (Laca et al., 1992), while the footstep was defined as each movement of the forelegs. These data were used to calculate the number of stations per minute, displacement rate (steps/ minute) and number of steps between stations. The daily number of feeding stations was obtained by multiplying the grazing time by the number of feeding stations per minute. The daily number of steps was determined by multiplying the grazing time by the rate of displacement. The number of bites per station was calculated by dividing the number of daily bites by the daily number of feeding stations. By the division between grazing time and the daily number of stations, it was calculate the time per feeding station.

The collection of forage as grazed (Euclides et al., 1992) was carried out by two trained raters, who observed one tester-heifer per paddock. Samples were dried in forced draught oven at $55^{\circ} \mathrm{C}$ for 72 hours. Dry samples were ground in a Wiley type mill through a $1 \mathrm{~mm}$ - mesh. Crude protein (984.13 method, AOAC, 1995) and insoluble fiber in neutral detergent (Van Soest et al., 1991) were measured at these samples.

The forage allowance ( $\mathrm{kg}$ of DM/100 kg of BW) was calculated as it follows: ((forage mass/number of days) + daily rate of accumulation of DM)/stocking rate and it is expressed as $\mathrm{kg}$ of dry matter/100 kg body weight. The green leaf allowance was calculated by the equation: (((Forage mass of leaves * \% leaves)/number of days) + daily rate of accumulation of $\mathrm{DM} * \%$ leaves)/stocking rate, expressed as $\mathrm{kg}$ of DM/100 kg body weight.

The estimated forage disappearance was calculated according to the equation:

$\mathrm{FD}=100-((\mathrm{RFM} * 100) /(\mathrm{IFM}+\mathrm{DAR})-\mathrm{LOSS}))$, where $\mathrm{FD}=$ disappearance rate of forage post-grazing; $\mathrm{RFM}=$ value of forage mass pre-grazing; IFM = value forage mass post-grazing; DAR = accumulation rate of herbage for the period and LOSS $=$ loss of forage $(\mathrm{kg} / \mathrm{ha} /$ day of $\mathrm{DM})$. The values of forage disappearance divided by the number of days in each period resulted in the daily disappearance of forage. This value, divided by the stocking rate and multiplied by 100 , was considered as the intake of forage, expressed in \% of BW. This intake value multiplied by BW of the testers-heifers led to the estimated forage intake, expressed in $\mathrm{kg} / \mathrm{animal} /$ day of DM. The bite mass was calculated by dividing the daily estimated forage intake by the daily number of bites (Jamienson \& Hodgson, 1979).

A completely randomized design following a repeated measurement over time was used with six and three area replications of exclusively Italian ryegrass and of pasture with supplement, with observations on 12 and 6 animals, respectively. The data were subjected to analysis of variance and $\mathrm{F}$ test at 5\% significance using the MIXED procedure of SAS statistical program, version 8.2 (2001). 


\section{Results and Discussion}

There was no alternatives of supplementation $\times$ periods of utilization interaction for the variables related to pasture $(\mathrm{P}>0.05)$. These variables were not influenced $(\mathrm{P}>0.05)$ when the heifers received supplement, which indicates that stocking rate management ensured similar grazing conditions for both, either heifers receiving supplement or exclusively on pasture. Variables related to pasture were affected $(\mathrm{P}<0.05)$ by pasture periods of utilization (Table 2$)$.

Stocking rate variation among periods of pasture utilization ( $\mathrm{P}=0.0128$ ) was caused due to the adjustments that were made in order to maintain values of forage mass between 1,000 and $1,500 \mathrm{~kg} / \mathrm{ha}$ of $\mathrm{DM}$. The sward height was lower in the second period $(\mathrm{P}=0.0114)$. On oats plus Italian ryegrass pasture is recommended a management to maintain the sward at a $10 \mathrm{~cm}$ height for greater animal production per area. However, for individual gains, higher canopy heights are recommended (Lopes et al., 2008).

The forage on offer was lower at the beginning of the occupation period of paddocks ( $\mathrm{P}=0.0029)$. Leaf blade on offer $(\mathrm{P}=0.0386)$ and leaf:stem ratio $(\mathrm{P}<0.0001)$ were lower in the last period due to reproductive stage of ryegrass. Macari et al. (2007) observed, on oats and Italian ryegrass, leaf blade on offer values between 3.6 and $4.7 \mathrm{~kg}$ of live weight. Silva et al. (2005) reported no difference on performance of steers grazing ryegrass managed under leaf biomass between 350 and $600 \mathrm{~kg} / \mathrm{ha}$ of DM. Thus, only at the end of occupation period of paddocks the leaf blade biomass value of $279.2 \mathrm{~kg} / \mathrm{ha}$ of DM was below the limit of $350 \mathrm{~kg} / \mathrm{ha}$ tested by these authors.

The stem and dead material masses were higher at the end of grazing cycle $(\mathrm{P}<0.05)$. The largest participation of these components may hinder grazing and limit bite mass (Barthram, 1981), as these components can be a barrier to grazing as well as the greater energy required to harvest stem instead of leaves (Hendricksen \& Minson, 1980).
There was an interaction between alternatives of supplementation $\times$ evaluation dates for grazing $(\mathrm{P}>0.05)$, rumination $(\mathrm{P}=0.0038)$ and idle $(\mathrm{P}<0.05)$ times. There was no adjustment for any regression model (Figure 1 ).
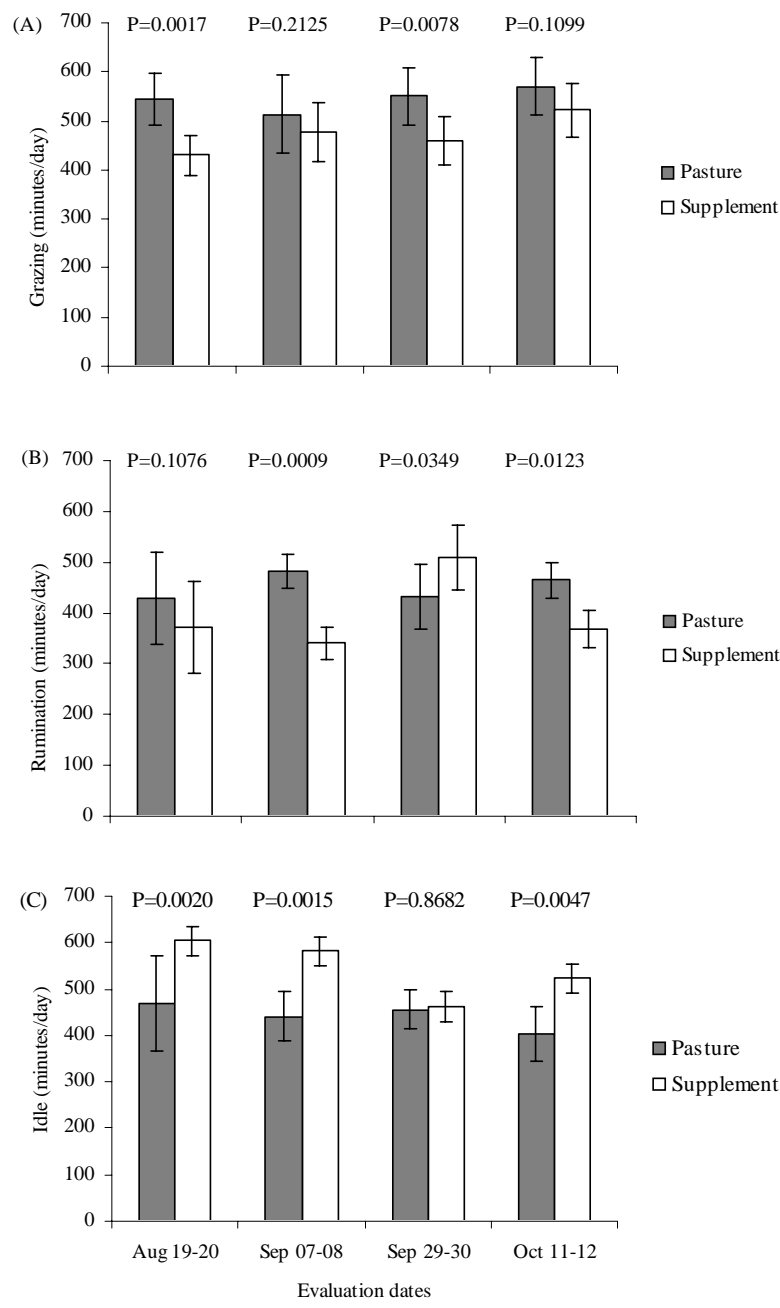

Figure 1 - Grazing (A), rumination (B) and idle (C) time of beef heifers on Italian ryegrass pasture receiving supplement or exclusively on pasture. Error bars indicate the standard deviation.

Table 2 - Stocking rate and Italian ryegrass pasture structural parameters

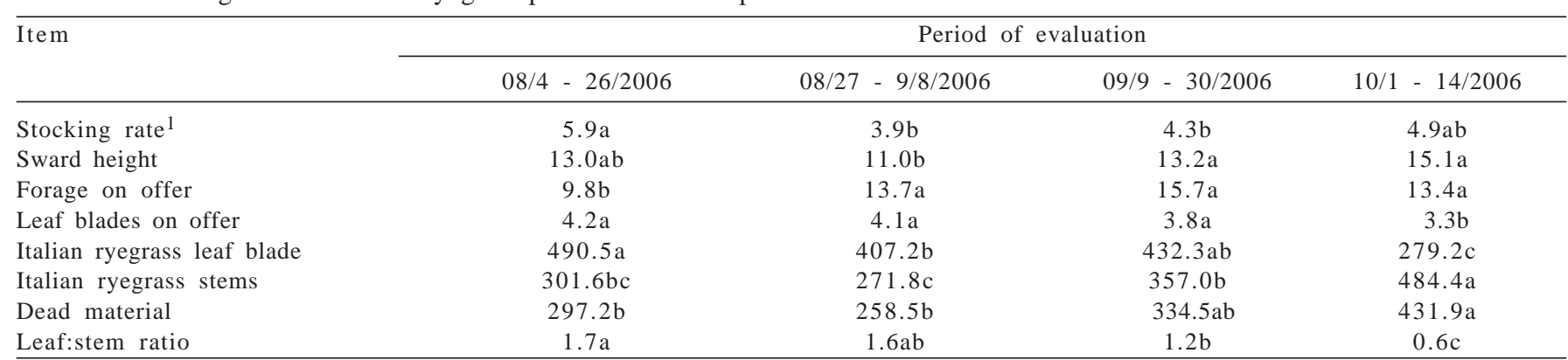

Means followed by different letters in lines are different $(\mathrm{P}<0.05)$ by Lsmeans test.

${ }^{1}$ Stocking rate: $\mathrm{Y}=5.66-0.09 \mathrm{x}+0.0011 \mathrm{x}^{2} ; \mathrm{R}^{2}=31.47 ; \mathrm{P}=0.0077 ;$ Forage on offer: $\mathrm{Y}=9.43+0.27 \mathrm{x}-0.0031 \mathrm{x}^{2} ; \mathrm{R}^{2}=58.0 ; \mathrm{P}=0.0004 ;$ Leaf blades on offer: $\mathrm{Y}=4.28-0.012 \mathrm{x}$; $\mathrm{R}^{2}=22.06 ; \mathrm{P}=0.0206$ 
The grazing time was lower for supplemented heifers in the first and third assessments. It has been suggested that grazing time decreases for supplemented heifers on oats and ryegrass pasture (Bremm et al., 2005; Macari et al., 2007). Also, in the first assessment there was no difference for rumination time between supplemented heifers and those exclusively on pasture. The Italian ryegrass at an initial stage of development has a high concentration of soluble and low concentration of structural carbohydrates, which should have allowed similar rumination time for both heifers, supplemented or not. Moreover, according to Burger et al. (2000) the supply of concentrate may reduce rumination time.

However, in the second and fourth evaluations, grazing and rumination time were similar between supplemented heifers and those exclusively on pasture. Pasture characteristics measured in the second evaluation showed a lower leaf blade mass than the first and fourth assessments. In addition, there were lower leaf blade on offer and leaf:stem ratio and higher stem mass in this assessment compared to the previous one. Probably, the combination of these factors was responsible for restricting forage apprehension and grazing time increase for supplemented heifers. The stems can be a barrier to achieve a deeper grazing because it requires greater force to be harvested (Laca \& Ungar, 1992) and cause an increase on rumination time because of its more fibrous constitution.

For exclusively on pasture animals, the idle time was lower in the first, second and fourth assessments. The iddle time variation is related to exclusionary character of ingestive behavior activities (Carvalho et al., 2001), which is represented by a negative correlation $(\mathrm{P}<0.001)$ between idle time with rumination (-0.7) and grazing time (-0.57).

The time spent by heifers at the trough was similar $(\mathrm{P}=0.7059)$ throughout the evaluation periods. Supplemented heifers remained 35.15 minutes/day, on average, at the trough while Bremm et al. (2005) reported 55.83 minutes when wheat bran was used as supplement. The faster consumption of supplement may be adequate for rainy days and when the presence of too many birds on the place can cause supplement contamination (Horn et al., 2005).

There were no interaction between alternatives of supplementation $\times$ evaluation dates $(\mathrm{P}>0.05)$ for chemical composition of forage when grazed. The chemical composition of selected diet was similar for supplemented or not supplemented heifers ( $\mathrm{P}>0.05)$ and it had average contents of $88.5 \%$ organic matter, $36.4 \%$ neutral detergent fiber and $24.8 \%$ crude protein. The forage chemical composition differed $(\mathrm{P}<0.05)$ among assessment dates with no changes in the organic matter content $(\mathrm{P}>0.05)$. The crude protein and neutral detergent fiber were adjusted for quadratic regression model. The crude protein content increased by $0.43 \%$ until the $43^{\text {rd }}$ day and then it declined $0.005 \%$ per day $\left(Y=17.176+0.432 \mathrm{x}-0.005 \mathrm{x}^{2} ; \mathrm{R}^{2}=57.2\right.$; $\mathrm{P}=0.0006$ ) while neutral detergent fiber concentration was $0.758 \%$ reduced until the $63^{\text {rd }}$ day, and then it increased $0.006 \%$ per day thereafter $\left(Y=55.662-0.758 x+0.006 x^{2}\right.$; $\mathrm{R}^{2}=72.7 ; \mathrm{P}=0.0241$ ).

Exclusively on pasture heifers or receiving supplement consumed similar amount of DM from forage $(\mathrm{P}=0.0882)$, crude protein $(\mathrm{P}=0.9896)$ and neutral detergent fiber $(\mathrm{P}=0.7299)$. The estimated intake of DM from forage and crude protein were 5.9 and $1.67 \mathrm{~kg} /$ day of DM (3.5 and $0.87 \%$ of live weight) respectively, therefore 19 and $63 \%$ lower than estimated by NRC (1996) for this animal category. The intake of $\mathrm{DM}$ from forage was similar $(\mathrm{P}=0.0882)$ for heifers at both supplementation alternatives and this can explain the absence of difference in the stocking rate, as supplemented heifers did not reduce forage intake, what could be expected in high quality pastures (Rearte \& Pieroni, 2001).

The bite rate $(\mathrm{P}=0.0384)$, feeding stations/minute $(\mathrm{P}=0.0192)$ and bites/feed station $(\mathrm{P}=0.0181)$, steps between feeding stations $(\mathrm{P}=0.0223)$ and displacement rate $(\mathrm{P}=0.0188$; Table 3) differ among evaluation dates.

The bite rate in the last assessment was higher than in the first one $(\mathrm{P}=0.0384)$. At this occasion the lower leaf blade on offer $(\mathrm{P}=0.0386)$, resultant of the smaller proportion of leaf blades $(\mathrm{P}=0.0006)$ and reduced leaf:stem ratio

Table 3 - Bite rate, feeding stations and beef heifers displacements patterns on Italian ryegrass pasture

\begin{tabular}{|c|c|c|c|c|}
\hline \multirow[t]{2}{*}{ Variable } & \multicolumn{4}{|c|}{ Evaluation dates } \\
\hline & $08 / 19-20$ & $09 / 7-8$ & $09 / 28-29$ & $10 / 11-12$ \\
\hline Bite rate (bite/minute) & $53.3 b$ & $54.7 \mathrm{ab}$ & $56.2 \mathrm{ab}$ & $60.6 a$ \\
\hline Feeding stations/minute & $11.1 \mathrm{a}$ & $10.5 a b$ & 9.3b & $10.5 \mathrm{ab}$ \\
\hline Bites/feed station & $4.9 \mathrm{~b}$ & $5.4 \mathrm{ab}$ & $6.4 \mathrm{a}$ & $5.9 \mathrm{a}$ \\
\hline Steps between feeding stations & $1.6 \mathrm{ab}$ & $1.4 \mathrm{~b}$ & $1.8 \mathrm{a}$ & $1.3 \mathrm{~b}$ \\
\hline Displacement rate (steps per minute) & $17.6 \mathrm{a}$ & $14.2 \mathrm{~b}$ & $14.9 \mathrm{~b}$ & $13.9 b$ \\
\hline
\end{tabular}

Means followed by the same lower case letters in lines are not different $(\mathrm{P}>0.05)$ by Lsmeans test. 
$(\mathrm{P}<0.0001)$ caused a higher value of bite rate. Positive correlation was found between bite rate and stem mass $(\mathrm{r}=0.64 ; \mathrm{P}=0.0042)$. Steers on black oats plus Italian ryegrass pasture increased the number of bites per unit of time when grazing in a lower leaf blade biomass (Trevisan et al., 2005). According to Hodgson (1990), on pastures with low forage on offer, the increase in bite rate occurs to compensate the decrease in bite mass in order to maintain the intake rate.

The number of feeding stations per minute was lower $(\mathrm{P}=0.0192)$ in the third evaluation, but this value did not differ from those obtained in the second and fourth assessments. The permanence time of animals at each feeding station is determined by the quantity of leaves (Prache \& Rouguet, 1996). In the second, third and fourth assessments, the forage on offer was higher than in the first evaluation ( $\mathrm{P}=0.0029$; Table 2 ), which may have affected the apprehension of leaves that still remained in a non limiting biomass (Trevisan et al., 2005). At this situation, the heifers were stimulated to carry out more bites in the same feeding station $(\mathrm{P}=0.0181)$ and to increase the time spent in selection of areas for achieving these bites. The difficulty in the apprehension of leaves can also be represented by the lower leaf:stem ratio in the second, third and fourth assessments, regarded to the first evaluation.

The number of steps between feeding stations was variable among evaluation dates, while the rate of displacement decreased numerically throughout the evaluation period, being higher in the first evaluation $(\mathrm{P}=0.0188)$. The highest rate of displacement in the first assessment, followed by the high number of steps among feeding stations, may have been caused by the higher stocking rate $(\mathrm{P}=0.0128)$ and lower forage on offer $(\mathrm{P}=0.0029)$ in this assessment even if leaf blade on offer was lower only in the last evaluation (Table 2). As group size increases, the greater each one's distance covered to achievement of individual requirements (De Vries, 1996).
There was alternatives of supplementation $\times$ evaluation dates interaction for bite daily number $(\mathrm{P}<0.05)$, feeding station number $(\mathrm{P}=0.0053)$ and time at feeding station ( $\mathrm{P}=0.0330$ ), in seconds (Table 4).

The daily number of bites was lower for supplemented heifers in the two initial periods of assessment (Table 3), when ryegrass was at vegetative stage, and leaf:stem ratio was greater than in later periods (Table 2). The assurance that the bite number is greater at higher green leaves on offer (Prache \& Rouguet, 1996) was only appropriate for heifers exclusively on pasture. The daily number of bites was positively correlated to grazing time $(\mathrm{r}=0.61$; $\mathrm{P}<0.0001)$.

The grazing time and number of daily feeding stations visited $(\mathrm{P}=0.0053)$ were 13.23 and $25.54 \%$ reduced, respectively at 08/19-20/2006 evaluation (Figure 1 ).

The correlation between these two variables was 0.57 $(\mathrm{P}<0.0001)$. In grazing animals, according to Hodgson \& Brookes (1999), factors that interfere with forage intake are: "feeding drive" or nutrient requirements of the herbivore; "physical satiety" or factors associated with distension of the alimentary tract; and "behavioral constraints" or limits due to the sum of factors of pasture plus factors of animal operating in ingestive behavior. Thus, the combination of lower grazing time, fewer stations visited and smaller daily number of bites suggests that supplemented heifers depend less on forage nutrients when grazing on ryegrass at the vegetative stage.

The heifers on 'Pasture' stayed longer at each feeding station ( $\mathrm{P}=0.0436)$ on the third evaluation. On this occasion, in relation to previous assessment, there were differences $(\mathrm{P}<0.05)$ in ryegrass tillers biomass and canopy height, which increased 26.9 and $16.7 \%$, respectively. The greater time spent at the same feed station by heifers exclusively on pasture probably was a compensation for the negative changes in the easiness of forage apprehension. In natural grassland, Gonçalves et al. (2009) reported that heifers remained 6.6 seconds at each feeding station, carrying 6.5 bites in each one. On steers grazing oats plus ryegrass pasture, Trevisan et al. (2005) observed a length of 18.1 and

Table 4 - Ingestive behavior components and beef heifers displacement for supplemented animals (S) and for those that received no supplement $(\mathrm{P})$ on Italian ryegrass pasture

\begin{tabular}{|c|c|c|c|c|c|c|}
\hline \multirow[t]{3}{*}{ Date } & \multicolumn{4}{|c|}{ Daily number } & \multicolumn{2}{|c|}{ Time at feeding station (s) } \\
\hline & \multicolumn{2}{|c|}{ Bite } & \multicolumn{2}{|c|}{ Feeding station } & \multirow[b]{2}{*}{$\mathrm{P}$} & \multirow[b]{2}{*}{ S } \\
\hline & $\mathrm{P}$ & S & $\mathrm{P}$ & S & & \\
\hline $09 / 7-8$ & $29,652.0 \mathrm{a}$ & $24,136.0 \mathrm{~b}$ & $5,521.6$ & $4,890.7$ & 6.5 & 5.6 \\
\hline $09 / 28-29$ & $29,824.0$ & $26,577.0$ & $4,703.0$ & $4,623.9$ & $8.3 \mathrm{a}$ & $6.7 \mathrm{~b}$ \\
\hline 10/11-12 & $34,228.0$ & $31,995.0$ & $6,057.5$ & $5,380.3$ & 6.4 & 6.2 \\
\hline
\end{tabular}

Means followed by the same lower case letters in lines are not different $(\mathrm{P}>0.05)$. 
19.1 seconds of permanence in each feeding station in August and September, respectively, without interference of tested levels of leaf blades biomass.

Heifers exclusively on pastures walked 8473 steps/day, 1674 more than the supplemented ones $(\mathrm{P}=0.0281)$. There was positive correlation between total number of steps and grazing time $(r=0.62 ; \mathrm{P}<0.0001)$. The animals on 'Pasture' traveled greater distances on paddocks and visited more feeding stations per minute, while the supplemented ones, probably had their nutrient requirements met with less displacement and smaller number of visited stations. However, Adams (1985) observed that the greater selectivity of the supplemented animals was related to the greater distances traveled by them. Pardo et al. (2003) reported that providing energetic supplement to steers grazing native grasslands resulted in reduction of grazing time and number of bites and an increase in idle time.

The bite mass, measured in organic and dry matter was higher for heifers receiving supplement $(\mathrm{P}<0.05)$, probably because supplemented heifers are more efficient on selecting areas of pasture that enable heavier bites (Krisl \& Hess, 1993). The bite mass for supplemented heifers was, on average, $0.23 \mathrm{~g}$ of organic matter and 0.26 g of DM per bite $(\mathrm{P}<0.0001)$, while for heifers on 'Pasture' the bite mass was of 0.19 and $0.22 \mathrm{~g}$ of organic and dry matter per bite, respectively. The organic matter values of bite mass are within the range reported by Stobbs (1973), from 0.05 to 0.80 g per bite, whose variation is dependent on the availability and accessibility of forage. Bite mass of $0.24,0.23,0.21$ and $0.36 \mathrm{~g}$ organic matter per bite were observed for calves on oats and ryegrass pasture receiving wheat bran in the daily proportion of $0,0.5,1.0$ and $1.5 \%$ of live weight, respectively (Bremm et al., 2005).

The bite mass is the ingestive behavior variable most influenced by canopy structure (Chacon \& Stobbs, 1976) and, at this experiment, the canopy structure descriptors variables were similar $(\mathrm{P}>0.05)$ for the two groups of heifers. The easiness of grazing depends on forage bulk density (Carvalho, 1997) and the greater bite mass for the supplemented animals may be related to bite performance in sites where the forage bulk density required less defoliation effort. Probably these places had higher density of leaf blades as the leaves require less energy to be harvested (Hendricksen \& Minson, 1980).

The bite mass, major mechanism of grazing animals to regulate nutrient intake, is the basis for adjustments made by animals spending more time chewing or making new bites in order to maintain the daily intake of nutrients (Prache \& Peyraud, 2001). The negative correlations obtained for this variable with grazing time, bite rate, the daily number of feeding stations and daily number of bites (Table 5) suggests the strategy used by grazing heifers on 'Pasture', which resulted in lower bite mass.

Beef heifers that not received supplement probably spent more time selecting forage to be harvested, which reflected in a greater grazing time, daily number of feed stations visited and performed bites. The chemical composition similarity in the forage harvested in the two alternatives tested was caused, then, by the different grazing strategies.

Table 5 - Correlations between bite mass and ingestive behavior variables of beef heifers on Italian ryegrass pasture

\begin{tabular}{lcccc}
\hline \multirow{2}{*}{ ttem } & \multicolumn{4}{c}{ Bite mass } \\
\cline { 2 - 5 } & \multicolumn{2}{c}{ Organic matter } & Dry matter \\
\hline Grazing time & -0.59 & $\mathrm{P}=0.0092$ & -0.60 & $\mathrm{P}=0.0085$ \\
$\begin{array}{l}\text { Bite rate } \\
\text { Daily number of }\end{array}$ & -0.52 & $\mathrm{P}=0.0276$ & -0.51 & $\mathrm{P}=0.0288$ \\
feeding stations & -0.67 & $\mathrm{P}=0.0021$ & -0.68 & $\mathrm{P}=0.0021$ \\
Daily number of bites & -0.73 & $\mathrm{P}=0.0006$ & -0.73 & $\mathrm{P}=0.0005$
\end{tabular}

\section{Conclusions}

The beef heifers ingestive behavior, displacement and search for forage patterns on Italian ryegrass pasture are modified by the effects of daily supply of concentrate and sward structural variation throughout periods of pasture utilization. The amount of forage harvested per bite (bite mass) of supplemented heifers is greater. At the reproductive stage of ryegrass, grazing time and feeding stations patterns of utilization are similar between supplemented heifers and those not receiving supplement.

\section{References}

ADAMS, D.C. Effect of time of supplementation on performance, forage intake and grazing behavior of yearling beef grazing Russian roildrygrass in the fall. Journal of Animal Science, v.61, n.4, p.1037-1042, 1985.

ASSOCIATION OF OFFICIAL ANALYTICAL CHEMISTRY AOAC. Official methods of analysis. 16.ed. Arlington: AOAC International, 1995. 1025p.

BREMM, C.; ROCHA, M.G.; RESTLE, J. et al. Efeito de níveis de suplementação sobre o comportamento ingestivo de bezerras em pastagem de aveia (Avena strigosa Schreb.) e azevém (Lolium multiflorum Lam.). Revista Brasileira de Zootecnia, v.34, n.2, p.387-397, 2005.

BARTHRAM, G.T. Sward structure and the depth of grazed horizon. Grass and Forage Science, v.36, p.130-131, 1981.

BÜRGER, P.J.; PEREIRA, J.C.; QUEIROZ, A.C. et al. Comportamento ingestivo em bezerros holandeses alimentados 
com dietas contendo diferentes níveis de concentrado. Revista Brasileira de Zootecnia, v.29, n.1, p.236-242, 2000.

CARVALHO, P.C.F; RIBEIRO FILHO, H.M.N; POLI, C.H.E.C. et al. Importância da estrutura da pastagem na ingestão e seleção de dietas pelo animal em pastejo. REUNIÃO ANUAL DA SOCIEDADE BRASILEIRA DE ZOOTECNIA, 38., 2001, Piracicaba. Anais... Piracicaba: FEALQ, 2001. p.853-871.

CARVALHO, P.C.F. A estrutura da pastagem e o comportamento ingestivo de ruminantes em pastejo. In: SIMPÓSIO SOBRE AVALIAÇÃO DE PASTAGENS COM ANIMAIS, 1, Maringá. Anais... Maringá: Universidade Estadual de Maringá, 1997. p.25-52.

CHACON, E.; STOBBS, T.H. Influence of progressive defoliation of a grass sward on the eating behavior of cattle. Australian Journal of Agriculture Research, v.7, n.3, p.709-727, 1976.

DE VRIES, M.W. Effects of resource distribution patterns on ungulate foraging behavior: A modelling approach. Forest Ecology Management, p.167-177, 1996.

EUCLIDES, V.P.B.; MACEDO, M.C.M.; OLIVEIRA, M.P. et al. Avaliação de diferentes métodos de amostragem sob pastejo. Revista Brasileira de Zootecnia, v.21, n.4, p.691-702, 1992.

GARDNER, A.L. Técnicas de pesquisa em pastagens e aplicabilidade de resultados em sistemas de produção. Brasília: IICA/EMBRAPA-CNPGL. 1986. 197p. (Série publicações miscelâneas, 634).

GONÇALVES, E.N.; CARVALHO, P.C.F.; DEVINCENZI, T. et al. Relações planta-animal em ambiente pastoril heterogêneo: padrões de deslocamento e uso de estações alimentares. Revista Brasileira de Zootecnia, v.38, n.11, p.2121-2126, 2009.

HANCOCK, J. Grazing behaviour of cattle. Animal Breeding Abstract, v.21, n.1, p.1-13, 1953.

HILLESHEIM, A. Manejo do gênero Pennisetum sob pastejo. In: SIMPÓSIO SOBRE MANEJO DA PASTAGEM, 9., 1998, Piracicaba. Anais... Piracicaba: FEALQ, 1998. p.77-108.

HENDRICKSEN, R.; MINSON, D.J. The intake and grazing behaviour of cattle a crop of Lablab purpureus cv. Rongai. Journal of Agricultural Science, v.95, p.547-554, 1980.

HODGSON, J.; BROOKES, I.M. Nutrition of grazing animals. In: WHITE, J.; HODGSON, J. (Eds.) New Zealand pastures and crop sciences. New York: Oxford University, 1999. p.117-132.

HODGSON, J. Grazing management: science into practice. 1.ed. Longman Group, 1990. 200p.

HODGSON, J. Ingestive behavior. In: LEAVER, J.D. (Ed.) Herbage intake handbook. Hurley: British Grassland Society, 1982. p.113-136.

HORN, G.W.; BECK, P.A.; ANDRAE, J.G. et al. Designing supplements for stocker cattle grazing wheat pasture. Journal of Animal Science, v.83, p.69-78, 2005 (E. Suppl.).

JAMIESON, W.S.; HODGSON, J. The effect of variation in sward characteristics upon the ingestive behavior and herbage intake of calves and lambs under continuous stocking management. Grass and Forage Science, v.34, p.273-281, 1979.

KRYSL, L.J.; HESS, B.W. Influence of supplementation on behavior of grazing cattle. Journal of Animal Science, v.71, p.2546-2555, 1993.
LACA, E.A.; UNGAR, ED. Effects of sward height and bulk density on bite dimensions of cattle grazing homogeneous swards. Grass and Forage Science, v.47, p.91-102, 1992.

LACA, E.A.; UNGAR, E.D.; SELIGMAN, N.G.; et al. An integrated methodology for studying short-term grazing behaviour of cattle. Grass and Forage Science, v.47, p.81-90, 1992.

LOPES, M.L.T.; CARVALHO, P.C.F.; ANGHINONI, I. et al. Sistema de integração lavoura-pecuária: desempenho e qualidade da carcaça de novilhos superprecoces terminados em pastagem de aveia e azevém manejada sob diferentes alturas. Ciência Rural, v.38, n.1, p.178-184, 2008.

MACARI, S.; ROCHA, M.G.; PÖTTER, L. et al. Comportamento ingestivo diurno de novilhas de corte recebendo níveis de suplemento. Ciência Rural, v.37, n.6, p.1746-1752, 2007.

MOREnO, J.A. Clima do Rio Grande do Sul. Porto Alegre: Secretaria da Agricultura, 1961. 41p.

NATIONAL RESEARCH COUNCIL - NRC. Nutrient requirements of beef cattle. 7.ed. Washington D.C., 1996. 90p.

PARDO, N.M.P.; FISCHER, V.; BALBINOTTI, M. et al. Comportamento ingestivo diurno de novilhos em pastejo submetidos a níveis crescentes de suplementação energética. Revista Brasileira de Zootecnia, v.32, n.6, p.1408-1418, 2003.

PRACHE, S.; PEYRAUD, J. Foraging: behaviour and intake in temperate cultivated grassland. In: INTERNATIONAL GRASSLAND CONGRESS, 19., 2001, São Pedro. Proceedings... São Pedro: 2001. p.309-319.

PRACHE, S.; ROGUET, C. Influence de la structure du couvert sur le comportement d'ingestion. Clermont-Ferrand: Institut National de la Recherche Agronomique, 1996. p.22-24 (Rapport d'Activité 1992-1995).

ROSO, D.; ROCHA, M.G.; PÖTTER, L. et al. Recria de bezerras de corte em alternativas de uso da pastagem de azevém. Revista Brasileira de Zootecnia, v.38, n.2, p.240-248, 2009.

REARTE, D.H.; PIERONI, G.A. Supplementation of temperate pastures. In: International Grassland Congress, 19., 2001. Piracicaba. Proceedings... São Pedro: SBZ, 2001, p.679-689. 2001.

SILVA, A.C.F.; QUADROS, F.L.F.; TREVISAN, N.B. et al. Alternativas de manejo de pastagem hibernal: níveis de biomassa de lâminas foliares. Revista Brasileira de Zootecnia, v.34, n.2, p.472-478, 2005.

STATISTICAL ANALYSIS SYSTEM - SAS. User's guide. Version 8.2. Cary: Statistical Analysis System Institute, 2001. 943p.

STOBBS, T.H. The effect of plant structure on the intake of tropical pasture. II-Differences in sward, nutritive value and bite size of animals grazing Setaria anceps and Chloris gaiana at various stages of growth. Australian Journal of Agricultural Research, v.24, p.821-829, 1973.

TREVISAN, N.B.; QUADROS, F.L.F.; SILVA, A.C.F. et al. Efeito da estrutura de uma pastagem hibernal sobre o comportamento de pastejo de novilhos de corte. Revista Brasileira de Zootecnia, v.34, n.3, p.774-780, 2005.

VAN SOEST, P.J.; ROBERTSON, J.B.; LEWIS, B.A. Methods for dietary fiber, neutral detergent fiber, and nonstarch polysacharides in relation to animal nutrition. Journal of Dairy Science, v.74, p.3583-3597, 1991. 